Професор, доктор, вчитель і натхненник, Трудар науки - знас вчений $і$ студент, Хірург від Бога, лікар і письменник, Асоціації хірургів краю президент. П. Шеремет «Життя дарує людям...»

\title{
ЗАСЛУЖЕНОМУ ЛІКАРЮ УКРАЇНИ, ДОКТОРУ МЕДИЧНИХ НАУК, ПРОФЕСОРОВІ КАФЕДРИ ХІРУРГІЧНИХ ХВОРОБ МЕДИЧНОГО ФАКУЛЬТЕТУ УЖГОРОДСЬКОГО НАЦІОНАЛЬНОГО УНІВЕРСИТЕТУ ВАСИЛЮ РУСИНУ - 70
}

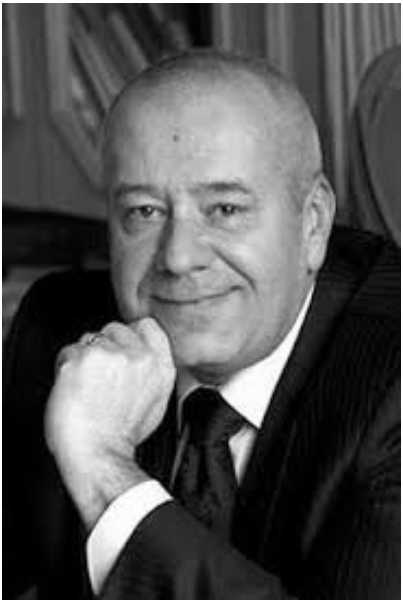

Ім’я Василя Русина для багатьох уже не одне десятиліття є синонімом професіоналізму, порядності, відданості справі та Батьківщині. Талановитий хірург, яскравий представник Закарпатської хірургічної школи, активний $\mathrm{i}$ невтомний дослідник. На перший погляд, дещо суворий, часом різкий, проте завжди готовий допомогти. Вимогливість, перш за все до себе, і дисципліна - основні життєві принципи ювіляра.

26 вересня 2019 року доктор медичних наук, професор Василь Іванович Русин відзначає свій 70-річний ювілей. Після закінчення у 1973 році медичного факультету Ужгородського державного університету Василь Іванович протягом 4 років працював хірургом у м. Тайшет Іркутської області. Але молодий хірург прагне вчитися та вдосконалюватися і у 1977 році вступає до аспірантури в Інститут серцево-судинної хірургії імені О.М. Бакулєва (м. Москва). У 1980 році успішно захистив кандидатську дисертацію на тему «Діагностика та хірургічне лікування посттромбофлебітичного синдрому здухвинно-стегнової локалізації». Талановитого науковця не могли не помітити і запропонували залишитися працювати у провідному інституті країни. Проте любов до рідного краю, бажання розвивати i покращувати хірургічну службу Закарпаття беруть гору над перспективною пропозицією, і з 1984 по 1987 рік Василь Іванович працює завідувачем хірургічного відділення обласної клінічної лікарні Закарпатської області. У 1987 році Русин В.І. розпочинає свою роботу в Ужгородському державному університеті, де проходить усі щаблі професійного росту - від асистента до завідувача кафедри госпітальної хірургії у 1998 році. Саме за час його завідування відбувається суттєве інтелектуальне становлення кафедри: за кількістю наукових публікацій, захищених дисертаційних досліджень кафедра займає провідні позиції не тільки у рідному навчальному закладі, але й гідно представляє Ужгородський національний університет на рівні держави. Невтомна праця над собою, вдосконалення дозволяють Василю Івановичу здобути визнання висококваліфікованого хірурга та науковця. У 1990 році успішно захистив докторську дисертацію на тему «Хірургічне лікування поєднаних оклюзійних уражень коронарних артерій та черевної аорти» в Інституті серцево-судинної хірургії імені А.М. Бакулєва (м. Москва) і був удостоєний наукового ступеня доктора медичних наук. У 1992 році ВАК України присвоїв Русину В.І. вчене звання професора. Заслуги вченого у розвитку вітчизняної хірургії були високо оцінені державою, i у 1999 році постановою Кабінету Міністрів Василю Івановичу Русину присвоєне почесне звання «Заслужений лікар України». Видатні організаторські здібності, успішне поєднання науковопедагогічної та громадської діяльності в університеті дозволяють Василь Івановичу у 2000 році очолити медичний факультет, а 32004 по 2005 рік зайняти посаду ректора Ужгородського національного університету. За плідну раціоналізаторську та винахідницьку діяльність, пов'язану з розробкою нових методів лікування та медичних приладів, у 2001 р. обраний членом-кореспондентом, а в 2002 p. - академіком Академії інженерних наук України та дійсним членом Угорської Академії наук. Професор Русин В.І. активно працює в галузі хірургічної науки і практичної діяльності. За період роботи виконано понад 6000 операцій, проконсультовано більше 5000 пацієнтів. Сферою його наукових інтересів $є$ абдомінальна хірургія, хірургія судин, хірургія ендокринних органів. Василь Іванович $є$ засновником дослідження і розробки методів діагностики медикаментозної i хірургічної корекції портальної гіпертензії. Під його керівництвом розроблені нові методи екстракорпоральної детоксикації при захворюваннях печінки, запроваджено нові технології в судинну хірургію. Професор Русин В.I. $є$ автором понад 730 публікацій, із них 47 монографій. Результатом наукових розробок стали 74 деклараційні патенти України на винаходи.

У 2008 році Василь Іванович отримав грамоту Державного департаменту інтелектуальної власності за сприяння розвитку винахідництва і раціоналізації в Україні, почесну грамоту Міністерства 
охорони здоров'я України за вагомий особистий внесок у розвиток охорони здоров'я та високий професіоналізм. У 2009 році професор Русин В.I. став лауреатом Державної премії України в галузі науки і техніки. Довгий час працював у ВАК членом експертної ради. Людина прославляє себе своїми учнями та добрими справами - під керівництвом професора Русина В.I. захищено 31 кандидатська та 12 докторських дисертацій. Василь Іванович $€$ незмінним головою оргкомітету міжнародних науково-практичних конференцій у м. Ужгород, систематично виступає 3 доповідями на різних вітчизняних та міжнародних наукових форумах. За час роботи в Ужгородському університеті професор Русин В.І. веде активну громадську діяльність, зокрема є президентом «Асоціації хірургів Закарпаття», членом президії Асоціації хірургів України, почесним членом президії асоціації хірургів-гепатологів СНД. За головуванням професора Русина В.І. інших рис та подиху набуло товариство хірургів Закарпатської області, що оцінила вся хірургічна спільнота України, відзначивши його досягнення найвищою професійною нагородою Відзнакою імені академіка Олександра Олексійовича Шалімова. Під час роботи конгресу ангіологів та судинних хірургів України, який відбувся в Києві, отримав почесну відзнаку «Судинний хірург 2014 року». Василь Русин неодноразово ставав номінантом щорічних конкурсів «Впливові люди Закарпаття», «Топ-100», «Топ-50» та «Лідер року Закарпаття». Людину завжди характеризують не лише за іiі професійними навичками, а i за іiі стилем життя та захопленнями. Загальний образ та стиль життя Василя Івановича можливо охарактеризувати одним словом: активність. Спорт, риболовля, мисливство, туризм - це все, що є присутнім в житті професоpa Русина B.I, це його надихає та підживлює його професійне життя, дає сили до роботи. Захоплення музикою, живописом, класичною літературою, поруч 3 такими рисами характеру, як поважне ставлення до співрозмовника та аргументоване відстоювання своєї позиції, непомітна допомога друзям, товаришам, колегам по роботі, життя за законам совісті і божими заповідями є свідченням інтелігентної людини, якою і повинен бути справжній лікар.

Високоповажний і дорогий Ювіляре! Від усього серця бажаємо Вам многая і благая літа при доброму здоров’і. Хай Бог, Доля і Ваші ангелиохоронці і надалі бережуть Вас і допомагають на складних життєвих дорогах!

Колектив кафедри загальної хірургіі медичного факультету Ужгородського національного університету

Колектив кафедри хірургічних хвороб медичного факультету Ужггородського національного університету 